\title{
ДИСКУССИИ
}

\section{Сохранение контроля над публичной компанией через выпуск акций с разными правами голоса. «За» и «против» избыточных прав на контроль}

\author{
Козлов Д.А. ${ }^{30}$, Чиркова Е.В. ${ }^{31}$
}

В данной статье представлен обзор механизмов усиления контроля над публичной компанией, результаты анализа теоретических обоснований использования акиий $c$ разныли правами голоса в качестве механизма усиления контроля над публичной компанией. Данный анализ проводился с иелью оценки целесообразности отмены запрета на выпуск акций с разными правами голоса в России.

Выпуск акций с разными правами голоса является механизмом защиты личных выгод контролирующего собственника, что подтверждается результатами многочисленных эмпирических исследований, в частности, исследованиями агентских издержек в компаниях, имеющих акциии с разными правами голоса. Анализ моделей оптимальной структуры акиионерного капитала показывает, что оптимальной с точки зрения акционеров является структура «одна акиия - один голос» и любое отклонение от данной схемь может приводить к снижению благосостояния миноритарных акционеров. С другой стороны, возможны ситуации, когда выпуск акций с разными правами голоса будет выгоден всем акционерам компании; однако такие случае единичньл.

В связи с наличием высоких агентских издержек в компаниях, имеющих в структуре акционерного капитала акциии с разными правами голоса, а также в силу слабой защиты прав миноритарных акиионеров в России делается вывод о нещелесообразности снятия запрета на выпуск акиий с разными правами.

JEL: G32, G34.

Ключевые слова: механизмы усиления контроля над публичной компанией, акции с разными правами голоса, компании с двумя классами акций, гипотеза «усиления стимулов окапьввания», структура акционерного капитала

\section{Введение}

Желание собственника сохранить контроль над компанией после того, как она становится публичной, способствовало возникновению механизмов усиления контроля (control enhancing mechanisms, далее - CEM), действие которых основывается на увеличении доли прав голоса без пропорционального увеличения доли прав на экономические выгоды ${ }^{32}$. Одним из СЕМ является выпуск нескольких классов акций с разными правами голоса и правами на экономические выгоды.

Возможность выпускать акции с разными правами голоса позволяет собственнику компании, владея лишь частью акций и только долей прав на экономические выгоды, полностью контролировать компанию, даже если его экономическая доля в компании

\footnotetext{
${ }^{30}$ Стажер-исследователь Лаборатории корпоративных финансов ГУ ВШЭ.

${ }^{31}$ К.э.н., доцент кафедры экономики и финансов фирмы ГУ ВШЭ.

32 Под «экономическими выгодами» здесь и далее понимается право на получение дивидендов, доходов от роста курсовой стоимости акций и имущественных прав, возникающих в случае банкротства компании. 
невелика и не дает ему прав на контроль при схеме «одна акция - один голос». В результате выпуска акций с разными правами голоса контроль над компанией достигается за счет инвестирования меньшей суммы собственных средств, чем в случае, если бы компания имела один класс акций, и пришлось бы выкупать 50\% плюс одну акцию.

Наличие выгод от выпуска акций с разными правами голоса привело к тому, что практика их использования распространилась в большинстве развитых стран. Результаты исследований показывают, что выпуск акций с разными правами голоса разрешен как минимум в 17 странах мира. Вместе с тем в России выпуск акций с разными правами голоса запрещен законом.

Наличие запрета на выпуск акций с разными правами голоса приводит к тому, что одни российские по происхождению компании инкорпорируются за пределами России в странах, где данный запрет отсутствует, другие - контролируются структурами с двумя классами акций, зарегистрированными в странах, где выпуск акций с разными правами голоса разрешен $^{33}$. Отмена запрета может к увеличению числа публичных компаний, зарегистрированных в России, что, в свою очередь, может способствовать росту налоговых поступлений в бюджет России.

Однако преимущества выпуска акций с разными правами голоса не однозначны. Причиной того, что в некоторых странах до сих пор действует принцип «одна акция - один голос», является тот факт, что выгоды для собственника оборачиваются высокими издержками для инвестора, нацеленного вложить средства в компанию, имеющую несколько классов акций. Высокие издержки объясняются тем, что у миноритарных акционеров отсутствует возможность контролировать действия менеджмента и влиять на принимаемые в компании решения. Результаты серии эмпирических исследований, как на развитых, так и на развивающихся рынках капитала, в которых исследуется взаимосвязь между концентрацией акционерного капитала и рыночной стоимостью компании, показывают, что, наличие избыточных прав на контроль оказывает негативное влияние на стоимость компании. В частности, Bennedsen, Nielsen (2008) показали, что стоимость средней европейской компании, имеющей несколько классов акций, на $19 \%$ ниже стоимости компании-аналога с одним классом акций. Размер дисконта зависит от типа контролирующего собственника, отрасли и правовой системы страны. Дисконт к стоимости компании будет выше, если компания подконтрольна семейной группе, либо компания оперирует в отраслях с высокими нематериальными выгодами, в первую очередь таких как «медиа», «индустрия развлечений» и «спортивные клубы». Помимо этого, наличие акций с разными правами голоса может вести к ущемлению прав акционеров, владеющих младшим классом, при поглощении компании. Так, существуют эмпирические подтверждения, что при поглощении компаний с двумя классами акций по акциям с большим числом голосов были выплачены большие премии. ${ }^{34}$

Целью данной статьи является оценка целесообразности внедрения в корпоративную практику России акций с разными правами голоса путем анализа различных аспектов, связанных с функционированием компаний, имеющих несколько классов обыкновенных акций, на развитых и развивающихся рынках капитала. Кроме того, результаты работы носят и образовательный характер и могут быть использованы для расширения спектра вопросов, изучаемых в настоящее время студентами российских ВУЗов, обучающихся на финансовых программах.

Статья организована в следующей последовательности. В первой главе приводится обзор СЕМ, среди которых - выпуск акций с разными правами голоса. Во второй главе

\footnotetext{
33 Примером является российская компания Yandex, материнская компания которой Yandex N. V. зарегистрирована в Голландии, и имеет два класса обыкновенных акций - акции класса А с одним голосом на акцию и акции класса В с десятью голосами на акцию. Источник: Газета «Коммерсантъ» № 70/П (4125) от 20.04.2009.

34 Законодательство ряда стран (в том числе, США) разрешает компании-покупателю выкупать акции у «младших» акционеров по меньшей цене, чем акции, имеющие большее право голоса.
} 
рассматривается практика использования акций с разными правами голоса в различных странах мира. В третьей главе проанализирована проблема концентрации акционерного капитала с позиции агентской теории. В четвертой представлены результаты анализа моделей оптимальной структуры акционерного капитала. В пятой главе приведены результаты исследований агентских издержек в компаниях, имеющих акции с разными правами голоса. В шестой главе разбираются ситуации, когда выпуск акций с разными правами голоса может быть выгоден для всех, в том числе миноритарных акционеров. В заключении суммируются результаты анализа и даются рекомендации о целесообразности использования акций с разными правами голоса в российской практике.

\section{1. Обзор механизмов усиления контроля над публичной компанией}

В исследовании Institutional Shareholder Services, Sherman \& Sterling LLP, European Corporate Governance Institute (2007) (далее - «исследование ЕС») и в работе Villalonga, Amit (2006) показано, что в мире существует как минимум 15 СЕМ. Наиболее часто используемые СЕМ могут быть условно разделены на три группы (см. Рис. 1). Выпуск акций с разными правами голоса относится к группе СЕМ, позволяющих усилить контроль за счет непропорционального увеличения доли прав голоса.

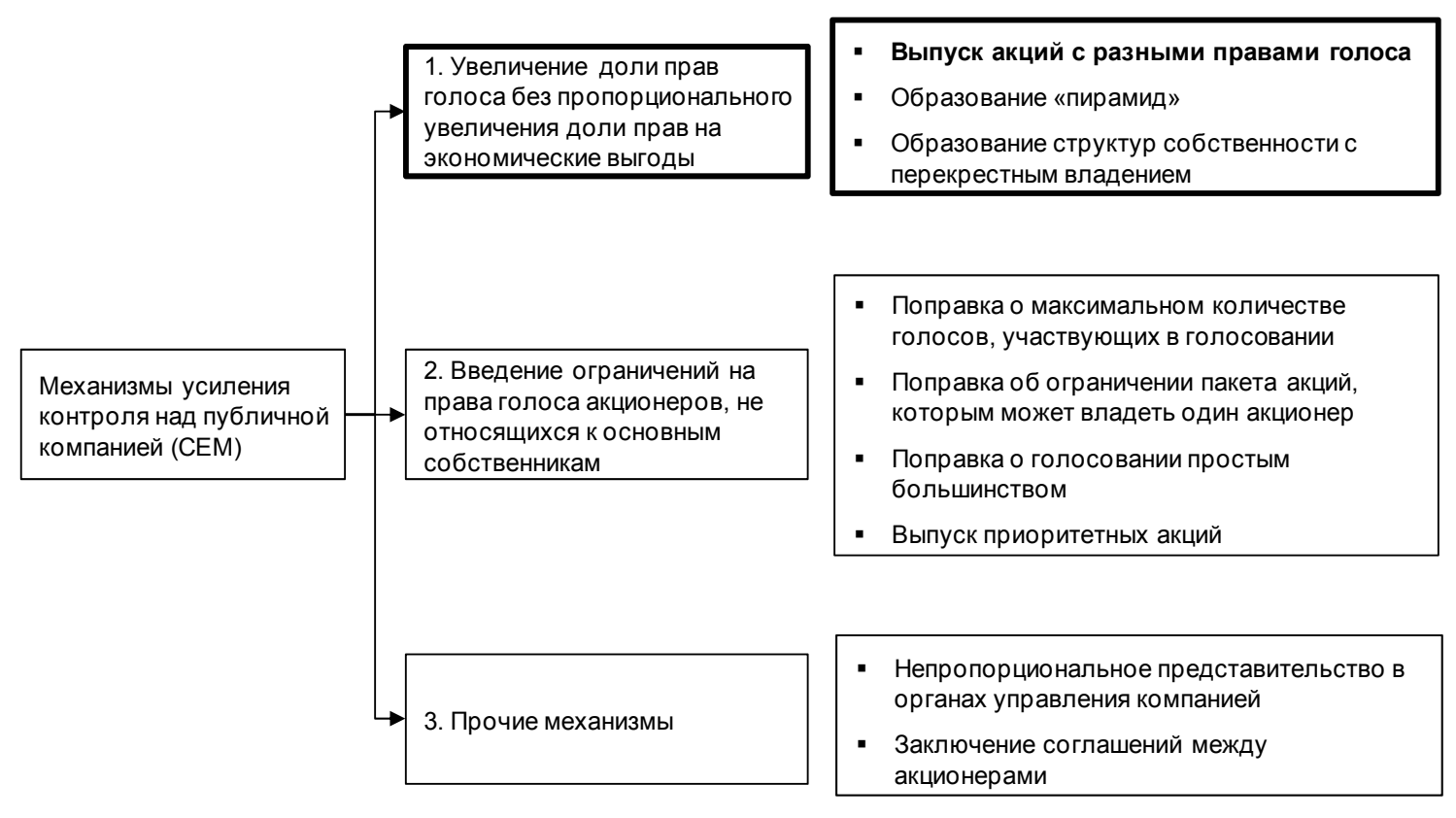

Рис 1. Классификация механизмов усиления контроля над публичной компанией

Выпуск акций с разными правами голоса

В большинстве развитых и части развивающихся стран собственник, желающий сохранить контроль над компанией после ее публичного размещения (initial public offering, далее - «ІРО»), имеет возможность создать структуру акционерного капитала, в которой ему будет принадлежать контрольная доля прав голоса и меньшая доля прав на экономические выгоды. Это может быть реализовано за счет выпуска обыкновенных акций с одинаковыми правами на экономические выгоды, но разными правами голоса. Выпуск акций с разными правами голоса, как правило, разрешен и регламентирован на законодательном уровне.

Поскольку у большинства компаний с несколькими классами акций всего два класса обыкновенных акций, то в англоязычной терминологии эти компании обычно называются компаниями с двумя классами акций (англ. - dual-class shares), хотя таких классов может быть больше. 
С точки зрения прав голоса различают четыре разновидности обыкновенных акций: неголосующие акции (англ. - non-voting shares); акции с ограниченным правом голоса, имеющие меньше одного голоса на акцию (англ. - limited-voting shares); акции, имеющие один голос на акцию; суперголосующие акции, имеющие более одного голоса на акцию (англ. - super-voting shares).

Акции с меньшим правом голоса часто называют подчиненным или младшим классом акций (англ. - inferior class), соответственно акции с большим правом голоса называют высшим или старшим классом (англ. - superior class).

В публичной компании с двумя классами акций контроль сохраняется за счет владения акциями старшего класса, а акции младшего класса публично размещаются на рынке. Владение акциями старшего класса означает, что контроль над компанией достигается за счет инвестирования меньших собственных средств, чем в случае, если бы компания имела один класс акций, и пришлось бы выкупать 50\% плюс одну акцию.

Структура акционерного капитала с акциями, имеющими разные права голоса, в научной литературе характеризуется следующими параметрами:

- отношение количества голосов акции старшего класса к количеству голосов акции младшего класса (англ. - voting ratio);

- отношение доли прав голоса, приходящейся на акции старшего класса к доле прав голоса, приходящейся на акции подчиненного класса (англ. - voting power distortion);

- избыточные права на контроль - разница между долями прав голоса и прав на экономические выгоды, приходящихся на акции старшего класса (англ. - excess control rights).

Дополнительное усиление контроля при выпуске акций с разными правами голоса достигается за счет использования пропорциональной схемы голосования. Согласно данной схеме акции старшего класса в дополнении к правам голоса, имеют права на выбор большинства членов совета директоров, соответственно акции младшего класса, голосуя общим числом, имеют права на выбор минимального количества членов совета директоров.

Примером IPO с двумя классами акций является публичное размещение компании Google, проведенное 19 августа 2004 г. Компания выпустила два класса акций: акции класса А с одним голосом на акцию и акции класса В с десятью голосами на акцию. На долю акций класса В пришлось 98,6 \% прав голоса и 87,6 \% прав на экономические выгоды. Акции класса А были частично распределены между сотрудниками компании, остальные размещены на бирже. Акции класса В не подлежали публичному размещению, и были сохранены за основателями компании - Ларри Пейджем и Сергеем Брином, менеджментом компании и другими лицами.

Образование «пирамид»

При помощи «пирамиды» контроль достигается за счет передачи прав голоса над компаниями по цепочке (см. Рис. 2). Собственник контролирует $51 \%$ компании 1 , которая в свою очередь контролирует 51\% компании 2, и так далее. 


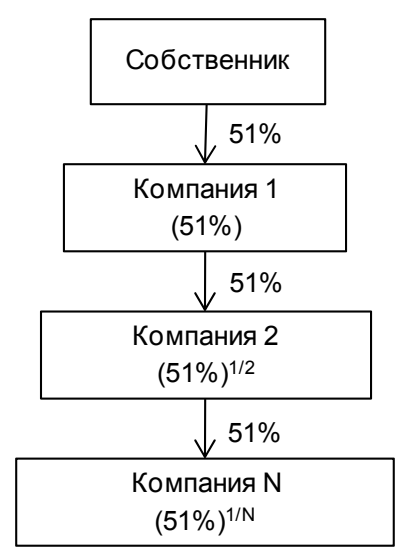

Рис. 2. Схема «пирамиды» (в скобках указана доля акционерного капитала, принадлежащая собственнику на каждом уровне «пирамиды»)

Если пирамида имеет $\mathrm{N}$ уровней, то собственнику нужно в $\mathrm{N}$ раз меньше собственных средств для получения контроля над компанией по сравнению с тем, что пришлось бы затратить при прямом инвестировании в эту компанию.

На практике встречаются многоуровневые «пирамиды». Известный пример семиуровневой «пирамиды» братьев Ван Сверинген приводится в книге Berle, Means (1932). Создание «пирамиды» позволило братьям Ван Сверинген контролировать сеть из восьми железных дорог, со стоимостью активов более 2 млрд. долл. США, инвестировав при этом менее 20 млн. долл. США собственных средств (см. Рис. 3).

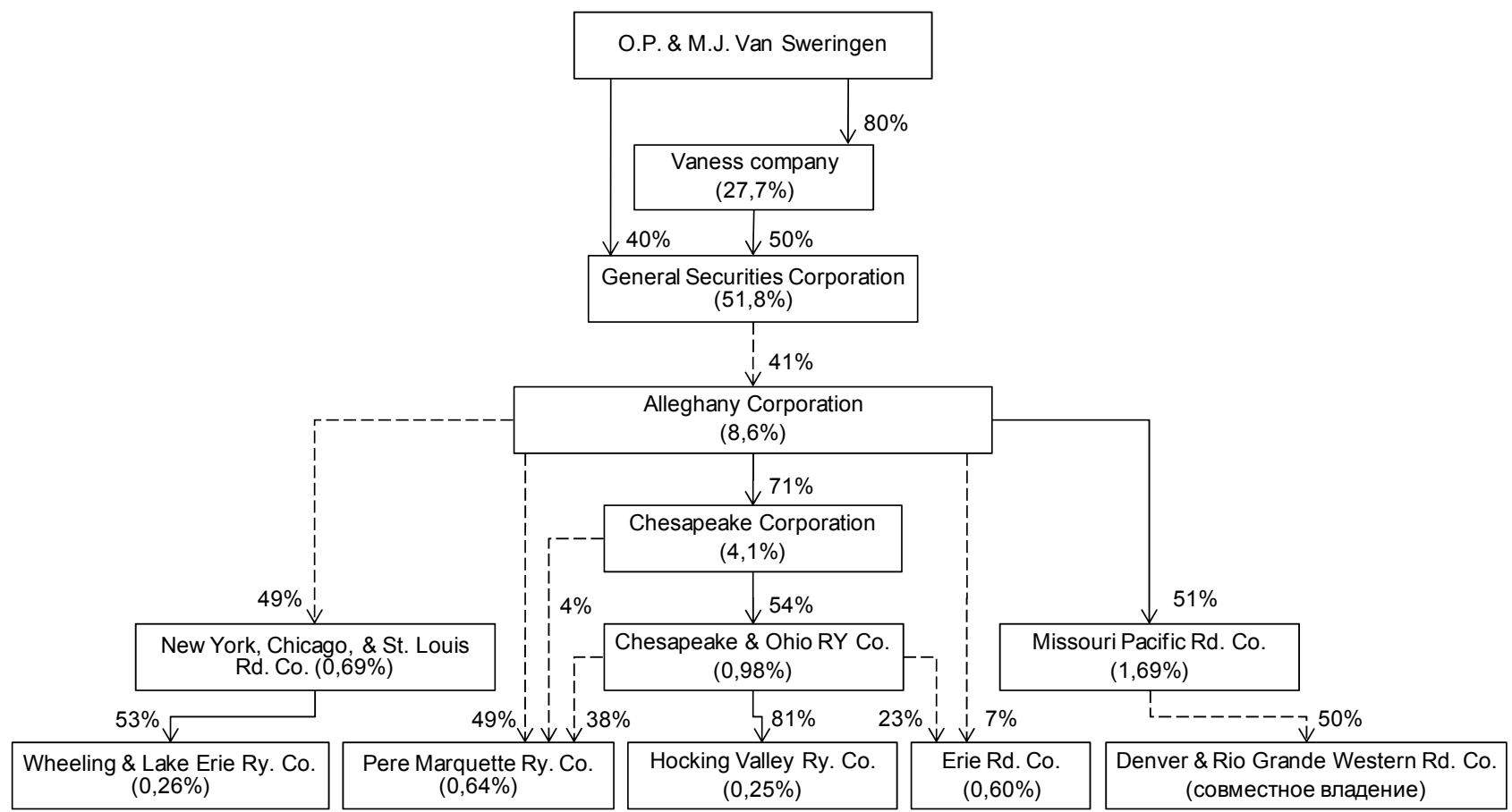

Рис. 3. Пирамида братьев Ван Сверинген (сплошными стрелками обозначено владение контрольным пакетом, пунктирными - неконтрольным. Проценты внутри прямоугольников показывают долю братьев Ван Сверинген в акционерном капитале компании, включая акции без права голоса) 
Образование структур собственности с перекрестным владением

В структуре собственности с перекрестным владением контроль достигается за счет перекрестной передачи прав голоса между компаниями. Собственник контролирует компанию 1, которая в свою очередь имеет долю в компании 2. Вместе с тем, компания 2 имеет долю в компании 1, и так далее. Отличие от «пирамиды» здесь в том, что права голоса, позволяющие получить контроль над структурой, распределяются между компаниями, а не сконцентрированы в руках одного собственника.

Собственник может иметь лишь малую долю прав на экономические выгоды во всех компаниях. Например, пусть собственник владеет одинаковыми долями в двух компаниях, которые имеют одинаковые перекрестные владения, и сумма долей, находящихся в прямом и перекрестном владении, в каждой компании не меньше 0,5 (см. Рис. 4).

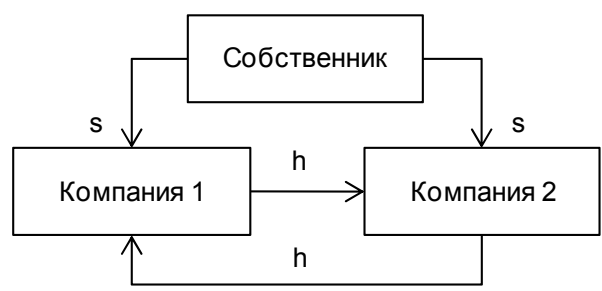

Рис. 4. Схема симметричной структуры собственности с перекрестным владением (s доли акционерного капитала компаний 1 и 2, принадлежащих собственнику, $\mathrm{h}$ - доли акционерного капитала, находящиеся в перекрестном владении)

Тогда доля прав собственника на экономические выгоды определяется как отношение доли акций, находящихся в прямом владении, к доле акций, не находящихся в перекрестном владении (верно только для симметричных перекрестных структур) равна $\alpha=s /(1-h)$.

Иногда публичные компании используют комбинацию СЕМ. Примером такой структуры является структура шведского холдинга семьи Валленберг, крупнейшего холдинга Северной Европы по данным на конец 2008 г. (см. Рис. 5).

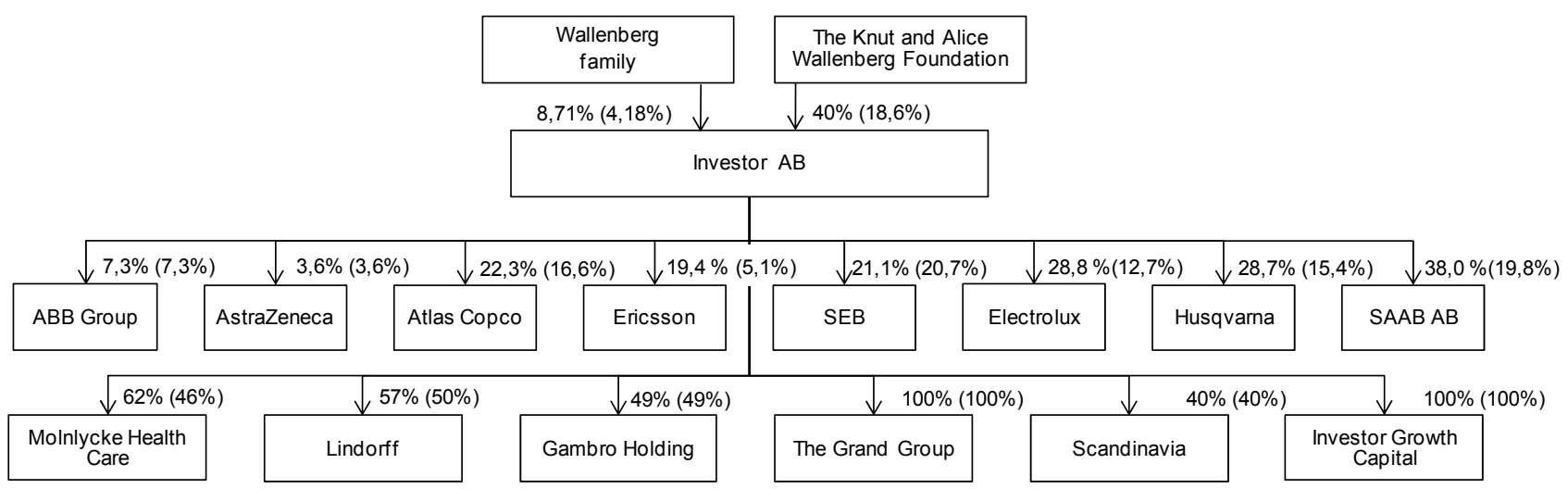

Рис. 5. Холдинг семьи Валленберг (показаны только прямые вложения) ${ }^{35}$

Семья Валленберг напрямую и через семейный фонд контролирует холдинговую компанию Investor AB. Акционерный капитал Investor AB состоит из акций класса А с одним голосом на акцию и акций класса В с 1/10 голоса на акцию. Семье Валленберг принадлежит большинство акций класса A. Investor $\mathrm{AB}$ имеет доли в 14 компаниях, контролируя за счет

${ }_{35}^{35}$ Источник: годовой отчет Investor AB, 2008 г., собственные расчеты. 
прямых вложений четыре компании. Кроме того, у компаний холдинга существуют перекрестные владения и доли в других компаниях (на рис. 5 не показаны).

\section{2. Практика использования акций с разными правами голоса для усиления контроля публичными компаниями}

Выпуск акций с разными правами голоса юридически разрешен в большинстве развитых и части развивающихся стран. В исследовании Nenova (2001) проведен анализ распространения компаний с двумя классами акций в 46 странам мира за 1992-2000 гг.. В «исследовании ЕС», инициированным Европейской Комиссией, выпуск акций с разными правами голоса рассмотрен наряду с остальными СЕМ на выборке из 20 крупнейших и нескольких менее крупных публичных компаний, либо недавно совершивших IPO в 16 странах ЕС, за период сентябрь - декабрь 2006 г.

В 17 странах мира (как минимум), а именно, в США, Канаде, Японии, Великобритании, Австралии, Финляндии, Франции, Ирландии, Дании, Венгрии, Нидерландах, Швеции, Норвегии, Италии, Мексике, Гонконге и ЮАР публичным компаниям разрешено выпускать акции с разными правами голоса и одинаковыми правами на экономические выгоды.

В 9 странах, а именно, в Германии, Эстонии, Греции, Люксембурге, Польше, Испании, Бельгии, Бразилии и Южной Корее публичным компаниям разрешено выпускать акции с разными правами голоса и разными правами на экономические выгоды (часто большими для акций подчиненного класса). В большинстве случаев компании выпускают неголосующие привилегированные акции, компенсируя повышенным дивидендом отсутствие прав голоса. По остальным странам полных данных нет, однако известно, что в Китае, Индии, Новой Зеландии, Турции, Малайзии, Швейцарии, Таиланде, Чили, Израиле, Саудовской Аравии компании могут выпускать более одного класса обыкновенных акций. В Китае существуют класс неголосующих акций, который запрещено держать иностранным гражданам. В Аргентине компаниям разрешено выпускать второй класс акций, однако такие акции не могут котироваться на бирже. Запрет на выпуск акций с разными правами голоса существует в России и Сингапуре. В федеральном законе РФ об акционерных обществах зафиксировано, что «каждая обыкновенная акция общества предоставляет акционеру - ее владельцу одинаковый объем прав» ${ }^{36}$.

В США число публичных компаний с двумя классами акций начало увеличиваться со второй половины 80-ых годов XX века. Рост числа компаний с двумя классами акций в США в это время объясняется отменой моратория на листинг компаний с двумя классами акций на Нью-Йоркской фондовой бирже (англ. - NYSE), который действовал с 1920-ых годов. Однако такой запрет действовал не повсеместно, и компаниям с двумя классами акций разрешено было котироваться на Американской фондовой бирже (англ. - AMEX), на американской фондовой бирже, специализирующейся на акциях высокотехнологичных компаний NASDAQ и уж тем более на мелких региональных биржах. В июне 1984 г. NYSE отменила мораторий на листинг компаний с двумя классами акций, что послужило импульсом к увеличению числа компаний, использующих данный СЕМ. По данным журнала Fortune в 2008 г. около 10\% всех публичных компаний в США имели акции с разными правами голоса, что в два раза больше по сравнению с данными на 1980 г. Статистика по IPO с двумя классами акций также свидетельствует о существенном росте интереса к данным структурам. По данным Fortune и Business Week доля IPO с двумя классами акций в США в 2002 г. составила 16,5\%, в 2001 $11 \%$, в то время как в 90-ых годах эта цифра составляла около $8 \%{ }^{37}$. По данным на 2006 г. 19 компаний из списка S\&P500 имели в структуре акционерного капитала акции с разными правами голоса.

\footnotetext{
${ }^{36}$ Федеральный Закон «Об акционерных обществах» №208, ст. 31, п. 1.

${ }^{37}$ Business Week March 29, 2004, 60.
}

Выпуск \#2(10), 2009 
Страновые различия в типе собственников, контролирующих компании с двумя классами акций

Как было сказано во введении, выпуск акций с разными правами голоса, прежде всего, выгоден семейным компаниям, желающим сохранить контроль после IPO, а также с наименьшими издержками обеспечить его наследственную преемственность.

La Porta, Lopez-de-Silanes, Shleifer (1999) показали, что публичные компании, использующие СЕМ, основанные на увеличении прав голоса без пропорционального увеличения прав на экономические выгоды, в большинстве случаев контролируются семейными кланами. Основными владельцами компаний с двумя классами акций в мире также являются семейные группы.

Большинство членов семейных кланов, которым принадлежит контроль над компанией, также принимают участие в наблюдении и управлении компанией. Согласно данным Nenova (2001) в более чем 70\% случаев члены семей занимают либо менеджерские позиции в компании, либо являются членами советов директоров. Подобный уровень вовлечения членов семейных групп наблюдается в каждой стране из выборки. Данный факт также подтверждается в статье La Porta, Lopez-de-Silanes, Shleifer (1999), авторы которой пришли к выводу, что в $71 \%$ случаев члены семей принимают участие в управлении компанией в качестве генерального директора, председателя совета директоров или вице-президента. Однако чаще члены семей занимают должности в совете директоров, чем занимаются оперативным руководством. По данным Gompers, Ishii, Metrick (2004), инсайдеры в компаниях с двумя классами акций в США владеют в среднем $60 \%$ голосов и 40\% прав на экономические выгоды. В одной трети всех компаний с двумя классами акций инсайдерам принадлежит более 50\% прав голоса и менее 50\% прав на экономические выгоды. Выборка крупнейших публичных компаний в США, контролируемых семейными кланами или основателями, представлена в табл. 1. 
Крупнейшие публичные компании с двумя классами в США (выборочно) ${ }^{38}$.

\begin{tabular}{|c|c|c|c|c|c|}
\hline \multirow[b]{2}{*}{ Компания } & \multirow{2}{*}{$\begin{array}{c}\text { Рыночная } \\
\text { капитализа } \\
\text { ция, млрд. } \\
\text { долл. США }\end{array}$} & \multicolumn{2}{|c|}{ Суперголосующие акции } & \multicolumn{2}{|c|}{$\begin{array}{c}\text { Контролирующие } \\
\text { собственники }\end{array}$} \\
\hline & & $\begin{array}{c}\text { \% от } \\
\text { рыночной } \\
\text { капитализа } \\
\text { ции } \\
\end{array}$ & $\begin{array}{c}\text { \%от } \\
\text { общих } \\
\text { прав } \\
\text { голоса } \\
\end{array}$ & $\begin{array}{c}\text { Имена } \\
\text { собственников }\end{array}$ & $\begin{array}{c}\text { \% от } \\
\text { общих } \\
\text { прав } \\
\text { голоса } \\
\end{array}$ \\
\hline Google Inc. & 141,4 & 26,0 & 77,9 & $\begin{array}{l}\text { Sergey Brin, } \\
\text { Larry Page }\end{array}$ & 57,5 \\
\hline $\begin{array}{l}\text { Comcast } \\
\text { Corporation }\end{array}$ & 81,4 & 0,3 & 33,3 & Brian Roberts & 33,3 \\
\hline News Corporation & 73,2 & 32,3 & 100,0 & $\begin{array}{l}\text { Rupert } \\
\text { Murdoch, } \\
\text { Harris Trust }\end{array}$ & 31,2 \\
\hline Viacom Inc. & 27,7 & 8,6 & 100,0 & $\begin{array}{l}\text { Summer } \\
\text { Redstone }\end{array}$ & 72,3 \\
\hline $\begin{array}{l}\text { Echostar } \\
\text { Corporation }\end{array}$ & 19,8 & 53,5 & 92,0 & $\begin{array}{l}\text { Cantey Ergen, } \\
\text { Charlie Ergen }\end{array}$ & 95,8 \\
\hline Broadcom Inc. & 18,5 & 13,6 & 61,2 & $\begin{array}{l}\text { Henry Samuelti, } \\
\text { Nicholas family } \\
\text { trust }\end{array}$ & 59,9 \\
\hline $\begin{array}{ll}\text { Ford } & \text { Motor } \\
\text { Company } & \end{array}$ & 14,8 & 3,7 & 40,0 & Ford family & 40,0 \\
\hline $\begin{array}{l}\text { Wm. Wrigley Jr. } \\
\text { Company }\end{array}$ & 13,8 & 21,6 & 73,4 & $\begin{array}{l}\text { William } \\
\text { Wrigley Jr. }\end{array}$ & 31,1 \\
\hline $\begin{array}{l}\text { The Hershey } \\
\text { Company }\end{array}$ & 12,6 & 26,4 & 78,2 & $\begin{array}{ll}\text { Two Hershey } \\
\text { trusts }\end{array}$ & 79,8 \\
\hline $\begin{array}{l}\text { IAC/Interactive } \\
\text { Corp. }\end{array}$ & 10,7 & 9,0 & 49,6 & $\begin{array}{l}\text { Barry Diller, } \\
\text { Liberty Media }\end{array}$ & 56,2 \\
\hline
\end{tabular}

Отраслевая специфика компаний с двумя классами акций

Результаты эмпирических исследований показывают, что компании с двумя классами акций наиболее распространены в таких отраслях как «медиа» («печатная и издательская деятельность», «радиовещание», «телевидение»), «индустрия развлечений» и «спортивные клубы». Компании из перечисленных отраслей в литературе также принято называть компаниями из отраслей с высокой «стоимостью удовольствия» (англ. - amenity value). Данный термин впервые введен в статье Demsetz, Lehn (1985), в которой исследовались факторы, влияющие на концентрацию акционерного капитала, на выборке 511 крупнейших публичных компаний США по данным на 1980 г. Авторы установили, что концентрация акционерного капитала зависит от отраслевого фактора и выше в отраслях «медиа», «индустрия развлечений», «спортивные клубы», что объясняется высокими нематериальными выгодами отраслей. Следует отметить, что выводы исследования базируются на данных 1980 г., когда размер фондового рынка США был значительно меньше, в том числе, в части распространения компаний с двумя классами акций.

Smart, Zutter (2003), исследовав IPO компаний с двумя классами акций по секторам экономики США за период 1990-1998 г., пришли к выводу, что они распространены в 54 из

38 Источник: финансовая отчетность компаний, журнал The Economist, Thomson DataStream. Рыночная капитализация по данным на 12 марта 2007 г. 
99 отраслей экономики, выраженных двухзначными кодами Стандартной отраслевой спецификации SIC (далее - «SIC-кодами»). При этом существуют три отрасли - «медиа», «индустрия развлечений» и «спортивные клубы», в каждой из которых количество IPO с двумя классами акций превышает 5\% от общего числа размещений.

В исследовании Gompers, Ishii, Metrick (2004), проведенного по рынку США на данных 1995-2002 гг., получены выводы о том, что компании с двумя классами акций наиболее распространены в пяти секторах экономики: «телекоммуникации», «бизнес-услуги», «печатная и издательская деятельность», «розничная торговля» и «машиностроение». При этом максимальная концентрация компаний наблюдается в секторах «телекоммуникации» и «медиа». Причиной распространения компаний с двумя классами акций в отрасли «телекоммуникации», по мнению авторов, является необходимость контроля выполнения стратегии, в отрасли «розничная торговля» это обеспечение индивидуальности и узнаваемости бренда. По отраслям «бизнес-услуги» и «машиностроение» возможные причины не приводятся. По нашему мнению возможными причинами может быть высокая концентрация семейных компаний в этих отраслях.

Объяснение, почему компании с двумя классами акциями более распространены в отраслях с высокой «стоимостью удовольствия» основано на предположении, что выпуск акций с разными правами голоса является механизмом защиты личных выгод собственника. Если личные выгоды велики и потеря контроля сопряжена с высокими «личными» издержками, то собственник предпочтет усилить контроль, выпустив акции с разными правами голоса. В свою очередь, личные выгоды могут быть двух типов:

- Личные материальные выгоды - связаны с извлечением части корпоративных ресурсов в ущерб остальным акционерам компании.

- Личные нематериальные выгоды - связаны с получением нематериальных благ различного характера (например, приобретение известности, престижа, получение удовольствия от владения бизнесом), что не всегда сопряжено с ущемлением прав «младших» акционеров.

В силу специфики бизнеса отрасли «медиа», «индустрия развлечений», «спортивные клубы» имеют наибольшие личные нематериальные выгоды. В отрасли «медиа» это возможность влиять на общественное мнение через средства массовой информации (далее СМИ), контролировать источники распространения информации, обладать «чувствительной» информацией, которая еще не доступна обществу. В отраслях «индустрия развлечений» и «спортивные клубы» это удовольствие от владения бизнесом (несмотря на то, что издержки, могут превышать доходы, что часто наблюдается, например, в профессиональных футбольных клубах. - Даниил Козлов), либо приобретение известности.

Таким образом, при равных возможностях для получения личных материальных выгод вероятность того, что компания выпустит акции с разными правами голоса будет выше для компании из отрасли с высокой «стоимостью удовольствия».

\section{3. Проблема концентрации акционерного капитала в агентской теории}

Агентская проблема (или проблема «принципал-агент», англ. - agency problem или principal-agent problem) заключается в том, что отделение прав на управление компаний от прав на экономические выгоды создает ситуацию ассиметрии информации, в которой менеджмент имеет возможность использовать свое положение для извлечения личных выгод. При прочих равных условиях размер агентских издержек зависит от структуры акционерного капитала, от ее концентрации и от того, в чьих руках сосредоточен контроль.

Высокая концентрация акционерного капитала в руках крупного акционера, не входящего в менеджмент, способствует усилению контроля действий менеджмента. Крупному акционеру, в отличие от мелких, легче контролировать действия менеджеров, так как у него есть для этого все необходимые ресурсы. Высокая концентрация акционерного капитала в руках крупного акционера, входящего в менеджмент, будет мотивировать его на 
максимизацию стоимости акционерного капитала. Berle, Means (1932) в своей классической работе «Современная корпорация и частная собственность» отмечают, что когда акционерный капитал распылен между большим числом мелких акционеров, и когда менеджмент имеет низкую долю в компании, то ресурсы компании могут быть использованы менеджментом для извлечения личных выгод. Позднее Jensen, Meckling (1976) показали, что агентские издержки снижаются по мере увеличения доли акционерного капитала в руках менеджмента. Данные выводы легли в основу «гипотезы усиления стимулов» (англ. insentive hypothesis), согласно которой результативность (выражающаяся в рыночной стоимости) компании увеличивается при росте доли акционерного капитала в руках менеджмента.

Недостатком «гипотезы усиления стимулов» является то, что она не учитывает тот факт, что высокая концентрация акционерного капитала позволяет менеджменту использовать контроль для извлечения личных выгод. В соответствии с этим была предложена альтернативная гипотеза - «гипотеза окапывания» (англ. - entrenchment hypothesis), согласно которой результативность компании снижается при росте доли акционерного капитала в руках менеджмента.

С учетом того, что обе модели являются линейными, то на основании них нельзя получить однозначные выводы о влиянии высокой концентрации акционерного капитала на результативность компании. Morck, Shleifer, Vishny (1988) предложили гипотезу о нелинейной взаимосвязи концентрации акционерного капитала и рыночной стоимости компании и показали, при какой концентрации, какая зависимость доминирует. Согласно «гипотезе окапывания - усиления стимулов» увеличение концентрации акционерного капитала до определенного момента положительно влияет на рыночную стоимость компании, после чего взаимосвязь становится отрицательной. Авторы исследовали выборку из 371 компаний из списка Fortune 500 на 1980 г. и получили следующие выводы: «гипотеза усиления стимулов» подтверждается, если членам совета директоров принадлежит 0-10\% в акционерном капитале, при увеличении концентрации акционерного капитала подтверждается «гипотеза окапывания».

Исследование проблемы концентрации акционерного капитала на выборке компаний с двумя классами акций позволяет оценить отдельно влияние доли прав на экономические выгоды («гипотеза усиления стимулов») и доли прав голоса («гипотеза окапывания») на результативность компании, а также исследовать влияние относительных показателей, таких как избыточные права на контроль.

Вместе с тем, увеличение диспропорции в правах голоса и правах на экономические выгоды приводит к тому, что эффект «окапывания» будет доминировать и можно предположить, что стоимость компании с двумя классами акций будет ниже стоимости компании-аналога с одним классом акций.

Результаты группы исследований, проводившихся в более 40 странах мира за 1991-2002 гг., подтверждают гипотезу Morck, Shleifer, Vishny (1988), а также доказывают, что эффект «окапывания» доминирует в компаниях, использующих акции с разными правами голоса и другие СЕМ (см. Табл. 2). Основные выводы исследований представлены ниже:

1. Структура акционерного капитала с двумя классами акций отрицательно влияет на стоимость компании. Дисконт к стоимости относительно компании-аналога с одним классом акций колеблется в диапазоне 6-25\% от рыночной капитализации.

2. Взаимосвязь между стоимостью компании с двумя классами акций и концентрацией акционерного капитала не линейна. Существует максимум избыточных прав на контроль, после которого стоимость компании снижается.

3. Влияние концентрации акционерного капитала зависит:

- от типа контролирующего собственника - отрицательное влияние сильнее, когда компания подконтрольна семейному клану; 
- совместно от уровня правовой защиты акционеров и типа контролирующего собственника - в странах со слабой правовой защитой наличие внешнего акционера является своего рода субститутом слабо развитых корпоративных механизмов защиты прав акционеров, поэтому увеличение концентрации положительно влияет на стоимость компании; в странах со слабой правовой защитой наличие крупного акционера - инсайдера отрицательно влияет на стоимость компании, что актуально для развивающихся стран.

- от отрасли, в которой компания осуществляет свою деятельность. Дисконт к стоимости максимален для компаний из отраслей с высокими нематериальными выгодами.

4. Использование других механизмов СЕМ, создающих диспропорцию в права голоса и правах на экономические выгоды также отрицательно влияет на стоимость компании. При этом нет однозначности в том, какой СЕМ оказывает максимальное отрицательное влияние на стоимость компании.

Таблица 2

Влияние концентрации акционерного капитала на стоимость компаний, использующих СЕМ

\begin{tabular}{|c|c|c|c|c|}
\hline Исследование & Страны & $\begin{array}{c}\text { Период } \\
\text { наблюдений }\end{array}$ & $\begin{array}{l}\text { Количество } \\
\text { компаний в } \\
\text { выборке }\end{array}$ & $\begin{array}{c}\text { Выводы о влиянии концентрации акционерного } \\
\text { капитала на рыночную стоимость компании, } \\
\text { использующей СЕМ }\end{array}$ \\
\hline $\begin{array}{l}\text { Amoako-Adu, } \\
\text { Smith, } \\
\text { Kalimipalli } \\
(2001)\end{array}$ & Канада & $\begin{array}{l}1998 \\
2000 \\
2002\end{array}$ & $\begin{array}{ll}403 & (73) \\
522 & (89) \\
456(79)\end{array}$ & $\begin{array}{l}\text { - VPD оказывает отрицательное влияние } \\
\text { - Средний дисконт для компании с двумя классами } \\
\text { акций } 12,86 \% \text { от балансовой стоимости активов } \\
\text { относительно компании-аналога с одним классом } \\
\text { акций }\end{array}$ \\
\hline $\begin{array}{l}\text { Claessens и др. } \\
(2002)\end{array}$ & $\begin{array}{l}\text { Гонконг, Индонезия, } \\
\text { Южная Корея, Малайзия, } \\
\text { Филиппины, Сингапур, } \\
\text { Тайвань, Таиланд }\end{array}$ & 1996 & 1301 & $\begin{array}{l}\text { - Подтверждение гипотезы Morck, Shleifer, Vishny - } \\
\text { максимум стоимости достигается при ECR = } 15 \% \\
\text { - Влияние отрицательное и зависит от типа } \\
\text { собственника, сильнее для семейных групп }\end{array}$ \\
\hline Lins (2003) & $\begin{array}{lr}\text { Аргентина, } & \text { Бразилия, } \\
\text { Чили, Чехия, Гонконг, } \\
\text { Индонезия, } \\
\text { Малайзия, } \\
\text { Филиаиль, } \\
\text { Сингапуры, Перу, Юортугалия, } \\
\text { Корея, } \quad \text { Шри-Ланка, } \\
\text { Тайвань, Таиланд, Турция }\end{array}$ & 1995 & 1433 & $\begin{array}{l}\text { - Зависит от типа собственника и уровня правовой } \\
\text { - } \text { ЕСщиты: } \\
\text { собственник - аутсайдер, отрицательное влияние, } \\
\text { если собственник - инсайдер } \\
\text { - Влияние ECR усиливается при более низком } \\
\text { уровне правовой защиты акционеров }\end{array}$ \\
\hline $\begin{array}{l}\text { Cronqvist, } \\
\text { Nilsson (2003) }\end{array}$ & Швеция & $1991-1997$ & 309 & $\begin{array}{l}\text { - Влияние VR отрицательное и зависит от типа } \\
\text { контролирующего собственника, сильнее для } \\
\text { семейных групп, не являющихся основателями } \\
\text { компании } \\
\text { - Размер агентских издержек } 6-25 \% \text { от рыночной } \\
\text { стоимости компании }\end{array}$ \\
\hline $\begin{array}{l}\text { Gompers, Ishii, } \\
\text { Metrick (2004) }\end{array}$ & США & $1995-2002$ & 748 & $\begin{array}{l}\text { - Подтверждение гипотезы Morck, Shleifer, Vishny - } \\
\text { максимум стоимости достигается при CFR = 60\%, } \\
\text { CFR }=\mathrm{VR}=30 \% \\
\text { - } \mathrm{ECR,} \mathrm{VR} \mathrm{оказывают} \mathrm{отрицательное,} \mathrm{CFR} \\
\text { положительное влияние }\end{array}$ \\
\hline $\begin{array}{l}\text { Maury, } \\
\text { Pajuste (2004) }\end{array}$ & Финляндия & $1993-2000$ & 136 & $\begin{array}{l}\text { - Влияние VPD отрицательное, зависит от типа } \\
\text { контролирующего собственника, и сильнее для } \\
\text { семейных групп } \\
\text { - Коэффициент при CFR статистически не значим }\end{array}$ \\
\hline Boubaker (2007) & Франция & 2000 & 510 & $\begin{array}{ll}\text { - } & \text { ECR, VR оказывают отрицательное влияние } \\
\text { - Отрицательное влияние показателя ECR сильнее, } \\
\text { чем VR }\end{array}$ \\
\hline $\begin{array}{l}\text { Bennedsen, } \\
\text { Niielsen (2008) }\end{array}$ & $\begin{array}{lr}\text { Австрия, Бельгия, Дания, } \\
\text { Финляндия, } & \text { Франция, } \\
\text { Германия, } & \text { Ирландия, } \\
\text { Италия, } & \text { Норвегия, } \\
\text { Португалия, } & \text { Испания, } \\
\text { Швеция, } & \text { Швейцария, } \\
\text { Великобритания }\end{array}$ & $1996-1998$ & 4096 & $\begin{array}{l}\text { - Влияние ECR отрицательное и сильнее для } \\
\text { компаний } \\
\text { o подконтрольных семейным группам } \\
\text { o из отраслей «медиа», «индустрия } \\
\text { развлечений», «спортивные клубы» } \\
\text { о низкой концентрацией денежных потоков } \\
\text { о в странах с сильной правовой защитой } \\
\text { акционеров } \\
\text { - Дисконт к стоимости для средней компании с } \\
\text { двумя классами акций 19\% относительно } \\
\text { компании-аналога с одним классом акций }\end{array}$ \\
\hline
\end{tabular}


Важно отметить, что исследование зависимости между рыночной стоимостью компании и концентрацией акционерного капитала сталкивается с проблемой эндогенности, то есть является вопросом «о курице и яйце». Возможно, не рыночная стоимость компании определяется концентрацией акционерного капитала, а наоборот. В упомянутой выше работе Demsetz, Lehn (1985) исследованы факторы, влияющие на концентрацию акционерного капитала публичных компаниях. Краткие выводы исследования Demsetz, Lehn (1985) таковы:

1. концентрация акционерного капитала тем выше, чем выше показатели нестабильности среды, в которой оперирует компания (индивидуальный риск вложения в акции компании, стандартное отклонение месячной доходности акций компании и бухгалтерской прибыли за год), то есть чем выше потенциальный выигрыш от мониторинга менеджмента.

2. концентрация акционерного капитала выше в компаниях из отраслей «медиа» и «спортивные клубы» по причине высоких нематериальных выгод.

3. концентрация акционерного капитала ниже в компаниях с большой рыночной капитализацией, так как, чем выше капитализация компании тем больше средств нужно затратить, чтобы приобрести большую долю в компании;

4. концентрация акционерного капитала ниже в компаниях бизнес, которых регулируется (отрасли «энергетика», «транспортировка газа»), так как снижает потенциальные личные выгоды собственников.

Следует отметить, что по нашему мнению, методология исследования Demsetz, Lehn (1985) имеет недостатки. В качестве показателей нестабильности в работе использованы стандартное отклонение месячной доходности и бухгалтерской прибыли, что, на наш взгляд, является некорректным в связи с эффектом сглаживания котировок. Если у публичной компании есть контролирующий собственник, то ему нет смысла «вздувать» котировки. Если он полностью контролирует менеджмент, то у менеджмента тоже (как и у основного собственника) нет мотивов сглаживать бухгалтерскую прибыль (а это нужно, чтобы «вздувать» котировки, так как инвесторы любят стабильную динамику).

В завершении приведем результаты опроса институциональных инвесторов об их отношении к СЕМ, проведенных в рамках исследования ЕС. В ходе анкетирования было опрошено 445 институциональных инвесторов из более чем 27-ми стран мира, под управлением которых находится ориентировочно 4,9 трлн. евро. Результаты показывают, что большинство инвесторов имеют отрицательное отношение к СЕМ. Наиболее негативно инвесторы относятся к использованию суперголосующих акций, приоритетных акций и поправок о максимальном ограничении голосов, участвующих в голосовании. Приведем цитату одного из респондентов:

«Отсутствие пропорциональности в правах голоса для акционеров является дополнительным риском, который должен быть включен в оценку компании. Риск увеличит затраты на капитал, и тем самым требуемая доходность по акциям компании возрастет. Это потребует от компании большей результативности и/или снизит цену ее акций».39

\section{4. Модели выбора оптимальной структуры акционерного капитала}

Исследования влияния концентрации акционерного капитала на рыночную стоимость компании не позволяют разработать механизмы, способствующие снижению агентских издержек в компаниях с двумя классами акций, а лишь фиксируют сам факт существовании агентской проблемы. Другим способом исследования агентской проблемы является моделирование оптимальной структуры акционерного капитала. Под структурой акционерного капитала обычно понимается распределение экономических прав и прав голоса между акциями, а также определение доли прав голоса, достаточной для принятия решения на собрании акционеров.

\footnotetext{
${ }^{39}$ Источник: ISS, Sherman \& Sterling LLP, European Corporate Governance Institute (2007). 
Наиболее значимыми работами по теме выбора оптимальной структуры акционерного капитала являются работы Grossman, Hart (1988) и Harris, Raviv (1988). Авторы обеих работ рассматривают структуру акционерного капитала с позиций того, кому она благоприятствует захватить контроль над компанией - стороне, намеревающейся извлекать из компании личные выгоды, или стороне, намеревающейся максимизировать рыночную цену акций. Обе модели рассматривают стоимость акционерного капитала V как сумму денежных потоков на акции $\mathrm{S}$ и личных выгод В от контроля над компанией:

$V=S+B$

Модели имеют разные предпосылки: в модели Grossman, Hart (1988) предполагается, что инвесторы по отдельности не могут оказывать влияние на результаты голосования, в то время как Harris, Raviv (1988) предполагают, что голос каждого может оказаться решающим в борьбе за контроль. Также Grossman, Hart (1988) рассматривают дискретные комбинации характеристик конкурирующих сторон, их варианты таковы: обе стороны имеют высокие личные выгоды; одна сторона имеет высокие личные выгоды; обе стороны не имеют высоких личных выгод. Harris, Raviv (1988) рассматривают непрерывную функцию характеристик конкурирующих сторон, одна из которых лучше другой с точки зрения управленческих навыков, то есть если она выиграет борьбу за контроль, то сможет максимизировать общую рыночную стоимость акций, включая личные выгоды и выгоды, доступные все акционерам.

Кроме того, в модели Grossman, Hart (1988) предполагается отсутствие асимметрии информации - инвесторы могут наблюдать обе вводимые характеристики менеджмента - его способности в максимизации денежных потоков и извлечении личных выгод, в то время как в модели Harris, Raviv (1988) личные выгоды не наблюдаемы.

Более поздние модели выбора оптимальной структуры акционерного капитала, например модель Chemmanur, Jiao (2006), учитывают асимметрию информации между менеджментом и акционерами компании. Авторы модели показали, что выбор оптимальной структуры акционерного капитала будет зависеть не только от соотношения между величиной денежного потока на акции и личными выгодами, но и наблюдаемой репутацией менеджмента, рискованностью инвестиционных проектов, реализуемых в компании, а также особенностями отрасли, в которой компания функционирует.

Кроме того, существуют модели, показывающие, что не во всех случаях собственнику компании может быть выгодно создавать структуры собственности с использованием СЕМ. Almeida, Wolfenzon (2005) показали, что влияние таких факторов как затраты на капитал, размер требуемых инвестиций для покупки новых активов, а также уровень прибыльности бизнеса могут приводить к тому, что собственник может отказаться от создания структуры капитала с избыточными правами на контроль.

\section{Модель Harris, Raviv (1988)}

Авторы предлагают модель, в которой предприниматель собирается инкорпорировать компанию, в преддверие чего, он должен решить две задачи - выбрать лучшую команду менеджмента, что позволит максимизировать стоимость акционерного капитала и поэтому будет оптимальным с точки зрения общества, а также максимизировать стоимость выпускаемых акций, что будет оптимальным с точки зрения предпринимателя. Стоимость выпускаемых акций будет зависеть от характеристик менеджмента, а также от размера ожидаемой премии за контроль в случае поглощения компании. Вместе с тем в модели рассматривается выбор оптимального правила голосования.

Авторы пришли к выводу, что принцип «одна акция - один голос» и принятие решений простым большинством (50\% голосов плюс один голос) являются оптимальными для общества, так как в компании с таким устройством в борьбе за контроль всегда побеждает лучшая команда менеджмента, то есть та, которая обеспечивает больший прирост цены акций. Однако, для того, чтобы максимизировать стоимость выпускаемых акций, предпринимателю выгодно выпустить два класса акций, первые - с правом голоса и без права 
на экономические выгоды, вторые - наоборот. Таким образом, структура акционерного капитала, оптимальная с точки зрения общества не является оптимальной с точки зрения предпринимателя, инкорпорирующего компанию. Преимуществом модели Harris, Raviv (1988) перед остальными моделями является учет оптимального выбора с точки зрения общества.

В силу оптимальности выпуска двух классов акций с точки зрения общества, на это может пойти и предприниматель. Ведь он тоже может оказаться заинтересован в максимизации стоимости компании, а тогда и в выпуске второго класса акций. Модель Harris, Raviv (1988) прогнозирует, что если компания объявляет о переходе с принципа «одна акция - один голос» на акции с разными правами голоса, то стоимость существующего акционерного капитала должна возрасти. Рост стоимости объясняется тем, что акционеры компании получают дополнительные возможности извлечь выгоды в виде премии за контроль в случае, если компания окажется поглощенной. Авторы отмечают, что данный факт является одним из предпосылок возникновения дискуссии об отмене моратория на листинг компаний с двумя классами акций на NYSE, который, как было указано выше, в результате имел место. Результаты эмпирических исследований по рынку США показывают неоднозначное отношение инвесторов к изменению структуры акционерного капитала, что объясняется фактом отмены моратория на листинг компаний на NYSE. Partch (1986) исследовала доходность 44 публичных компаний в США, выпустивших в период 1962-1984 гг. второй класс акций с ограниченными правами голоса, и обнаружила отсутствие реакции рынка на изменение структуры акционерного капитала. Позднее Jarrell, Poulsen (1988) исследовали доходность 94 компаний в США, выпустивших второй класс акций в период 1976-1987 гг. (59 компаний выпустили второй класс акций после 1984 г.), и зафиксировали отрицательную двухдневную избыточную доходность в среднем $-0,82 \%$.

\section{Модель Grossman, Hart (1988)}

Авторы рассматривают модель, в которой действующая команда менеджмента I делает тендерное предложение на покупку акций компании, однако в борьбе за контроль ей противостоит конкурент $\mathrm{R}$ - новая менеджерская команда. В данной ситуации акционеры компании решают, принять ли предложение одной из сторон, либо отказаться от продажи акций. Ввиду отсутствия ассиметрии информации и наличия рациональных ожиданий, акционеры с определенностью предвидят, какая команда победит. Также в модели рассматривается выбор оптимального правила голосования - процент, голосующих акций $\alpha$.

В модели рассматриваются два разных способа покупки акций: тендер без ограничений - покупатель обязан выкупить все акции компании по одинаковой цене, тендер с ограничениями - покупатель может ограничить свое предложение на покупке, как по цене, так и по количеству акций. Модель имеет несколько решений в зависимости от исходных предпосылок. В случае тендерного предложения без ограничений возможно 8 комбинаций борьбы за контроль в зависимости у кого есть личные выгоды и в зависимости от того, какая команда увеличивает поток денежных потоков (см. табл. 3).

Таблица 3.

Оптимальная структура акционерного капитала при тендере без ограничений

\begin{tabular}{|c|c|c|c|c|c|}
\hline & $\begin{array}{ll}\mathrm{B}_{\mathrm{I}} \text { высоки, } \\
\text { малы }\end{array}$ & $\begin{array}{l}\text { В I малы, } \\
\text { высоки }\end{array}$ & $\mathrm{B}_{\mathrm{R}}$ & $\begin{array}{l}\mathrm{B}_{\mathrm{I}} \text { высоки, } \\
\text { высоки }\end{array}$ & BI малы, BR малы \\
\hline $\mathrm{S}_{\mathrm{I}}>$ & $\begin{array}{l}\text { «1 акция }-1 \\
\text { голос» }\end{array}$ & $\begin{array}{l}\text { «1акция } \\
\text { голос» }\end{array}$ & -1 & $\begin{array}{l}\text { Отклонение от } \\
\text { схемы «1 акция - } \\
1 \text { голос» }\end{array}$ & $\begin{array}{l}\text { «1 акция }-1 \\
\text { голос» }\end{array}$ \\
\hline $\mathrm{S}_{\mathrm{I}}<\mathrm{S}_{\mathrm{R}}$ & $\begin{array}{l}\text { «1 акция } \\
\text { голос»» }\end{array}$ & $\begin{array}{l}\text { «1 акция } \\
\text { голос» }\end{array}$ & 1 & $\begin{array}{ll}\text { Отклонение } & \text { от } \\
\text { схемы } & \\
\text { « акция } & - \\
\text { голос» } & \end{array}$ & $\begin{array}{l}\text { «1 акция }-1 \\
\text { голос» }\end{array}$ \\
\hline
\end{tabular}


В ситуации, когда покупатель обязан выкупить все акции по одинаковой цене и обе конкурирующие за контроль стороны имеют большие личные выгоды, отклонение от схемы «одна акция - один голос» может быть оптимальным выбором с точки предпринимателя (см. табл. 3). Во всех остальных случаях оптимальной будет схема «одна акция - один голос». Кроме того, в ситуации, когда оптимальной схемой является «одна акция - один голос» выбор правила голосования не оказывает влияние на исход борьбы за контроль.

В ситуации, когда покупатель имеет возможность выкупить ограниченное количество акций, выбор оптимального правила голосования будет влиять на исход борьбы за контроль в ситуации, когда личные выгоды обеих команд высоки. Оптимальной структурой акционерного капитала в ситуации, когда только действующая команда имеет право покупать акции по разной цене, будет схема «одна акция - один голос», а также голосование простым большинством. В ситуации, когда обе стороны имеют возможность покупать акции по разной цене, оптимальной схемой будет также «одна акция - один голос». Оптимальным правилом голосования при этом будет количество голосов близкое к 50\%, если велика вероятность, что личные выгоды действующего менеджмента высоки, и количество голосов близкое к 100\%, если велика вероятность, что высоки личные выгоды нового менеджмента.

В случае если разрешены тендеры на покупку акций по разной цене, борьбу за контроль может выиграть худшая команда менеджмента. Например, пусть $\mathrm{S}_{\mathrm{I}}=60$ долл. США, $\mathrm{B}_{\mathrm{I}}=0$, $\mathrm{S}_{\mathrm{R}}=40$ долл. США, $\mathrm{B}_{\mathrm{R}}=15$ долл. США и действует правило голосования простым большинством. Новая команда менеджмента выиграет борьбу за контроль при покупке 50\% всех акций за 61 долл. США. Объясняется это тем, что если даже стоимость компании снижается до 50 долл. США, действующая команда менеджмента не может предложить больше, чем 60 долл. США в тендере на 100\% всех акций компании.

Результаты модели Grossman, Hart (1988) можно истолковать следующим образом:

1. Структура акционерного капитала должна затруднять поглощение, когда контроль хочет захватить менеджмент, который выплатит акционерам меньшие дивиденды, и наоборот, облегчать поглощение для тех, кто будет способен выплатить большие дивиденды;

2. Максимальную цену за голосующие акции предложат те менеджеры, которые могут извлечь наибольшие личные выгоды от контроля, а за акции, по которым платятся дивиденды, - те, кто может выплатить самые большие дивиденды;

3. Так как за голоса больше готов платить менеджмент, у которого больше личные выгоды, в случае, когда эта же команда предпочтительна для акционеров (увеличивает поток дивидендов), то выгодно разделить акции с правами голоса и правами на экономические выгоды. В этом случае победит лучший менеджмент, так как он предложит больше за голосующие акции. Если же, наоборот, присутствие новой команды менеджеров не выгодно для акционеров, то голоса должны быть привязаны к тем же акциям, что и дивиденды, так как худшая команда менеджеров предложит больше за голоса, а лучшая - больше за дивиденды. В итоге лучшая команда может и победить, так как в сумме предложит больше.

Основной недостаток модели Grossman, Hart (1988) состоит в еe теоретической направленности. В действительности существует проблема ассиметрии информации и как правило неясно, как оценить стремление команд менеджмента к личным выгодам и их способности к управлению поглощаемыми компаниями.

\section{5. Агентские издержки в компаниях с двумя классами акций}

Выше было сказано, что выпуск акций с разными правами голоса усиливает агентскую проблему из-за увеличения возможностей контролирующего собственника извлекать личные выгоды. Теоретически и эмпирически доказано, что существуют, как минимум, пять типов личных выгод в компаниях с двумя классами акций: 
1. Получение большей премии за контроль при поглощении компании;

2. Блокирование сделок при поглощении компании;

3. Неэффективное использование инвестиционных ресурсов;

4. Извлечение личных выгод при покупке или продаже активов;

5. Завышение собственных компенсационных выплат.

Получение большей премии за контроль при поглощении компании

Возможность неравномерного распределения премии за контроль между акционерами будет зависеть от способа покупки компании и законодательства, регулирующего сделки M\&A. Покупка компании может осуществляться двумя способами: публичное тендерное предложение (англ. - public takeover bid), либо через покупку блокирующего пакета (англ. block trade acquisition). Системы законодательства, регулирующие сделки М\&A основываются на одном из двух правил ${ }^{40}$ :

1. рыночное правило (англ. - market rule) - компания-покупатель, приобретающая блокирующий пакет, либо акции только одного класса не обязана делать предложение миноритарным акционерам о покупке их акций по цене, равной цене акции в блокирующем пакете.

2. правило равных возможностей (англ. - equal opportunity rule) - выражает три разновидности законов: равные возможности для всех классов акций при поглощении компании, равные возможности для миноритарных акционеров и блокирующего акционера в рамках одного класса акций при поглощении компании, обязательное предложение на покупку всех акций при покупке пакета акций, размером свыше порогового значения ${ }^{41}$.

В разных странах, как правило, доминирует одно из двух правил. В работе Nenova (2003) проанализированы системы законодательства в 18 развитых и развивающихся странах. В 13 странах законом установлено пороговое значение пакета акций, после которого компания-покупатель обязана предложить всем акционерам выкупить их акции. Значение порогового значения колеблется в диапазоне 10-67\% акций компании. В 5 странах компания-покупатель обязана приобретать акции разных классов по одной цене при тендерном предложении. В 8 странах при объявлении тендера компания-покупатель обязана заплатить миноритарным акционерам туже цену за свои акции, что и при покупке блокирующего пакета акций, либо по разным классам акций. Следует отметить, что рыночное правило полностью доминирует всего в двух странах - США и Мексике. В США проблема защиты прав акционеров решается либо на корпоративном уровне, путем введения соответствующих поправок в устав компании, таких как поправка о справедливой цене (англ.-fair price provision), либо на уровне отдельных штатов - закон о справедливой цене, (англ.-fair price law), что встречается значительно реже.

Существуют эмпирические подтверждения неравных выплат по акциям разных классов при поглощении компаний с двумя классами акций (см. Табл. 4). Как следует из Табл. 4 случаи неравных выплат чаще встречались в Великобритании, однако если суммировать все случаи в США, то цифра становится сопоставимой. Также из Табл. 4 следует, что исследование по рынку США выполнено по данным до отмены моратория на листинг компаний с двумя классами акций на NYSE.

\footnotetext{
${ }^{40}$ Терминология Bebchuk, Kraakman, Triantis (1999). Подробнее см. Bebchuk (1994), Albuquerque, Schroth (2008), La Bruslerie (2008).
} 
Неравномерные выплаты по акциям разных классов при поглощении компаний с двумя классами акций

\begin{tabular}{|c|c|c|c|}
\hline Исследование & $\begin{array}{c}\text { Страна, период } \\
\text { наблюдений }\end{array}$ & $\begin{array}{l}\text { Количество } \\
\text { наблюдений }\end{array}$ & Результаты \\
\hline $\begin{array}{l}\text { DeAngelo, } \\
\text { DeAngelo } \\
(1985)\end{array}$ & $\begin{array}{l}\text { США } \\
1960-1980\end{array}$ & 30 & $\begin{array}{l}\text { • } 4 \text { случая неравных выплат: } 83,3 \% \text {, } \\
100 \%, 140,2 \% \text { и } 200 \% \\
\text { • } 8 \text { случаев, когда выплаты были } \\
\text { равны, однако экономические } \\
\text { выгоды по младшему классу акций } \\
\text { были выше } \\
\text { • } 6 \text { случаев, когда информация о } \\
\text { неравных выплатах опубликована в } \\
\text { Wall Street Journal, однако } \\
\text { документальных подтверждений } \\
\text { найдено не было }\end{array}$ \\
\hline $\begin{array}{l}\text { Megginson } \\
(1990)\end{array}$ & $\begin{array}{l}\text { Великобритания } \\
1955-1982\end{array}$ & 43 & • 37 случаев неравных выплат \\
\hline
\end{tabular}

Блокирование сделок при поглощении компании

Блокирование сделки по поглощению компании может иметь место в ситуации, когда личные выгоды контролирующего собственника высоки. Если предложение о покупке акций содержит премию за контроль и выгодно миноритарным акционерам, то их благосостояние в результате блокирования сделки снижается.

Bebchuk, Kraakman, Triantis (1999) показали, что независимо от правового режима, регулирующего сделки M\&A, при наличии избыточных прав на контроль существует вероятность того, что в результате перехода контроля благосостояние миноритарных акционеров уменьшится. Это может иметь место, несмотря на высокую премию за контроль, которую готов заплатить новый собственник. Вероятность того, что при высокой премии за контроль действующий собственник откажется от сделки тем выше, чем ниже его доля прав на экономические выгоды и чем выше размер личных выгод

Неэффективное использование инвестиционных ресурсов

Деятельность компании сопряжена с выбором и реализацией инвестиционных проектов. При этом возможны ситуации, когда контролирующий собственник будет использовать свое положение для извлечения личных выгод. Так, Bebchuk, Kraakman, Triantis (1999) показали, что при наличии высоких личных выгод при инвестировании в проекты, собственник может выбрать менее прибыльный проект. При этом вероятность принятия неэффективного решения будет тем выше, чем ниже его доля прав на экономические выгоды.

Существуют эмпирические подтверждения о неэффективном использовании инвестиционных ресурсов в компаниях с двумя классами акций. Masulis, Wang, Xie (2006) исследовали выборку из 427 компаний с двумя классами акций в период 1995-2003 гг. Изучив зависимость между избыточной доходностью и изменением капитальных расходов за определенный период в зависимости от избыточных прав на контроль, авторы получили, что увеличение диспропорции в правах голоса и правах на экономические выгоды снижает эффективность капитальных вложений. При увеличении избыточных прав на контроль на 17,5\% стоимость 1 долл. США капитальных вложений для акционеров снижается на 38\%. Аналогичные выводы Masulis, Wang, Xie (2006) получили, заменив капитальные вложения 
денежными средствами на балансе компании. При увеличении избыточных прав на контроль на 18,1\% стоимость 1 долл. США денежных средств снижается на $10 \%$.

\section{Извлечение личных выгод при покупке или продаже активов}

Одной из форм личных выгод может быть желание увеличить размер активов под управлением с целью построить империю и/или извлекать еще больше личных выгод. Возможна и обратная ситуация, когда собственник продает активы компании на выгодных для него условиях, в то время как актив может быть прибыльный.

В теоретической модели Bebchuk, Kraakman, Triantis (1999), построенной в предположении о наличии личных выгод, вероятность принятия неэффективного решения резко увеличивается при снижении доли прав на экономические выгоды у контролирующего собственника. В данной модели компании с диспропорцией в правах голоса и правах на экономические выгоды имеют тенденцию к расширению, нежели чем к продаже активов и сохранению внутри компании свободных денежных потоков. Компании более склонны к трансформации в конгломераты, чем публичные компании, не имеющие диспропорции в правах голоса и правах на экономические выгоды.

Попытка оценить личные выгоды от контроля при покупке активов произведена Masulis, Wang, Xie (2006). Авторы проанализировали 410 сделок по поглощению компаний, совершенные 189 компаниями с двумя классами акций в период с 1995-2003 гг. Masulis, Wang, Xie исследовали эмпирическую зависимость между избыточной доходностью акций компаний с двумя классами акций в период объявления о сделке и величиной избыточных прав на контроль. Авторы пришли к выводу, что избыточные прав на контроль отрицательно влияют на избыточную доходность акций, что можно интерпретировать как извлечение личных выгод контролирующими собственниками. По нашему мнению, данный вывод не является вполне справедливым, так как известно, что в среднем акции компанийпокупателей в сделках M\&A демонстрируют отрицательную избыточную доходность в период объявления о сделке, поэтому эмпирическая проверка возможности использования данного механизма для получения личных выгод не является корректной.

\section{Завышение собственных компенсационных выплат}

Контролирующий собственник имеет возможности увеличить компенсации себе и своему окружению. Эмпирически подтверждено, что компенсационные выплаты генерального директора компании с двумя классами акций в среднем выше, чем в компании с двумя классами акций.

Smart, Zutter (2003) исследовали компенсационные выплаты генеральных директоров 900 компаний с одним классом акций и 229 компаний с двумя классами акций и получили, что средние (медианные) выплаты в первом случае составили 442368 (278 988) долл. США, во втором - 905649 (489 605) долл. США. Проведение регрессионного анализа для учета факторов, влияющих на размер компенсации - размера фирмы, отрасли, времени и других подтвердило первоначальные выводы. Авторы получили, что выплаты генерального директора в компании с двумя классами акций на 242000 долл. США выше, чем в аналогичной компании с одним классом акций.

Кроме того, существуют подтверждения того, что размер компенсации генерального директора тем выше, чем выше избыточные права на контроль. Masulis, Wang, Xie (2006) исследовали компенсации генеральных директоров 150 компаний с двумя классами акций в период 1995-2003 гг., и учтя факторы, влияющие на размер компенсации, получили, что чем выше избыточные права на контроль, тем выше компенсация генерального директора. Так, при прочих равных условиях, рост избыточных прав на контроль на 20,3\% соответствует росту компенсации генерального директора на 785110 долл. США. 


\section{6. Анализ выгод от выпуска акций с разными правами голоса, доступные всем акционерам}

Согласно предложенной в работе классификации выгоды от выпуска акций с разными правами голоса могут быть двух типов:

1. Выгоды стратегического характера.

2. Выгоды финансового характера.

\section{Выгоды стратегического характера}

\section{Возможность фокусирования на долгосрочном росте}

Данные выгоды могут быть в полной мере отражены высказыванием основателей компании Google Лари Пейдж и Сергей Брин, которые комментируют решение о выпуске акций с разными правами голоса:

«...Как частная компания мы концентрировались на долгосрочных ориентирах, что хорошо нам помогало. Как публичная компания, мы продолжим поступать также. По нашему мнению, внешнее давление на компании часто приводит к тому, что они вынуждены жертвовать возможностями долгосрочного развития в целях удовлетворения квартальных ожиданий рынка. Как говорит Уоррен Баффетт: «Мы не хотим «размазывать» квартальные или годовые результаты: если доходы большие, когда они достигают штаб-квартиры, они будут большими, когда достигнут вас». Если возникают возможности, которые могут заставить нас отказаться от краткосрочных целей в пользу долгосрочных интересов наших акционеров, мы будем использовать эти возможности...» ${ }^{42 .}$

Таким образом, выпуск акций с разными правами голоса позволяет максимизировать стоимость компании, основываясь на долгосрочных планах роста без боязни компании быть поглощенной.

Защита от поглощения бизнеса с рискованными и/или капиталоемкими и/или долгосрочными проектами

Основатель компании может использовать выпуск акций с разными правами голоса в условиях большой неопределенности и/или капиталоемкости и/или отдача от инвестиций ожидается через длительный период времени. Если бизнес компании в действительности окажется прибыльным, то защита от поглощения через выпуск акций с разными правами голоса повысит благосостояние акционеров.

Примеры компаний, для которых это может быть актуально: компании типа «старт-ап» (англ. - start up), компании из наукоемких отраслей, компании из отрасли «высокие технологии».

\section{Возможность создания репутации в бизнесе}

Данные выгоды могут быть в полной мере отражены высказыванием Уоррена Баффетта: «Чтобы построить репутацию требуется 20 лет, а чтобы ее разрушить 5 минут. Если вы подумаете об этом, то будете поступать по-другому». ${ }^{43}$

Репутация является одним из ключевых драйверов стоимости для компаний из отрасли «медиа». Члены семьи Ochs-Sulzberger, контролирующие компанию New York Times Co., выпускающую одноименное печатное издание, ответили отказом на предложение инвестиционной компании Morgan Stanley Investment Management об отмене второго класса акций, заявив, что избыточные права на контроль позволяют компании сохранять и укреплять такие важные для печатного издания принципы, как журналистская честность,

\footnotetext{
${ }^{42}$ Источник: S-1 Registration Statement, ”An Owner's Manual” for Google’s Shareholders, 2004. Большая часть этого руководства основана на ранее опубликованных эссе, годовых отчетах и "An Owner's Manual” компании Berkshire Hathaway, написанных У. Баффеттом.
}

${ }^{43}$ Источник цитаты не известен. 
непредвзятость и независимость ${ }^{44}$. В случае с отраслью «медиа» существует «обратная сторона медали» - отрасль «медиа» имеет высокий потенциал для извлечения личных нематериальных выгод, который, по мнению большинства исследователей, результатов эмпирических исследований (см. Табл. 2 выше) является более сильным стимулом для выпуска акций с разными правами голоса. С другой стороны высокие нематериальные выгоды являются дополнительным стимулом для собственника развивать компанию собственник имеет возможности для извлечения больших нематериальных выгод лишь в ситуации, когда его компания успешна (например, газета имеет высокий тираж). Таким образом, обоснования выпуска акций с разными выгодами для компании из отрасли «медиа» являются противоречивыми.

Примеры компаний, для которых это может быть актуально: компании из отраслей «медиа», «финансовые услуги».

Возможность выстраивать долгосрочные отношения с персоналом

Низкая вероятность поглощения позволяет руководству компании фокусироваться на привлечении, удержании и мотивации персонала в расчете на долгосрочную перспективу. Сохранение персонала важно для компаний, где персонал является носителем важных знаний и информации, обладает уникальными навыками и способностями. Данный фактор важен для компаний, большая часть стоимости которых создается за счет интеллектуального труда сотрудников. Сюда же можно отнести возможность осуществления инвестиций в формирование и сохранение команды менеджмента и совета директоров в расчете на долгосрочную перспективу.

Примеры компаний, для которых это может быть актуально: компании из отраслей «высокие технологии», «финансовые услуги», «медиа».

\section{Возможность создания сильной корпоративной культуры}

Долгосрочные контракты с менеджментом формируют в компании долгосрочные отношения среди подчиненных сотрудников, что с годами может превращаться в устойчивые связи и налаженные коммуникации. Сильная корпоративная культура положительно влияет как на репутацию компании, так и повышает операционную эффективность, что в итоге может создавать дополнительную стоимость для акционеров. Примером компании с двумя классами акций, имеющей одну из лучших в мире корпоративных культур, является Google. В 2007- 2008 гг. компания Google была признана лучшей, а в 2009 г. четвертой среди ста лучших работодателей США, по мнению журнала Fortune ${ }^{45}$.

\section{Финансовые выгоды}

Публичные компании могут сталкиваться с проблемой недофинансирования и «размытия» акционерного капитала. Например, рассмотрим компанию, у которой есть прибыльные, но рискованные инвестиционные проекты. Финансирование проектов за счет выпуска акций снижает долю прав голоса контролирующего собственника и увеличивает вероятность потери контроля из-за увеличения общего количества акций в обращении. Выпуск акций с разными правами голоса решает проблему «размытия» акционерного капитала, а также позволяет использовать акции в качестве постоянного источника для инвестиций. Приведем на эту тему цитату институционального инвестора, опрошенного в ходе исследования по странам ЕС: «Использование механизмов усиления контроля особенно важно в случаях использования рискованного капитала мелкими компаниями, испытывающими финансовые трудности. Это усиливает контроль и увеличивает доходность для того, кто предоставляет рискованное финансирование» ${ }^{46}$.

\footnotetext{
${ }^{44}$ Источник: The New York Times. October, 17, 2007. Morgan Stanley Sells New York Times Stake.

${ }^{45}$ Fortune. 100 best companies to work for $(2007,2008,2009)$.

${ }^{46}$ Источник: ISS, Sherman \& Sterling LLP, European Corporate Governance Institute (2007).
} 
Примеры компаний, для которых это может быть актуально: компании типа «старт-ап», компании из наукоемких и инновационных отраслей.

\section{Выводы}

В данной статье проанализированы теоретические и практические аспекты использования акций с разными правами голоса в качестве механизма усиления контроля над публичной компанией. Практика использования СЕМ показывает, что выпуск акций с разными правами голоса является распространенным механизмом сохранения контроля над публичной компанией среди многих развитых и развивающихся стран мира. Основными собственниками компаний с двумя классами акций являются семьи, что подтверждает предположение о том, что выпуск акций является механизмом защиты личных выгод, а также используется для обеспечения преемственности собственности для будущих поколений.

Результаты анализа моделей выбора оптимальной структуры акционерного капитала показывают, что оптимальной структурой в общем случае является «одна акция - один голос» и голосование простым большинством. Отклонение от схемы «одна акция - один голос» приводит к ситуациям, когда благосостояние миноритарных акционеров будет снижено.

В компаниях с двумя классами акций существуют большие возможности для извлечения личных выгод. Теоретические предположения о в таких компаниях существовании высоких агентских издержек в большинстве случаев подтверждаются эмпирическими наблюдениями. Так, например, в случае если закон не требует равных выплат всем акционерам при поглощении компании, то права акционеров могут быть ущемлены за счет того, что премии по акциям старшего класса будут выше, чем по акциям младшего класса.

Результаты эмпирических исследований в 40 странах мира в течение 1991-2002 гг. показывают, что стоимость компании с двумя классами акций ниже, чем компании-аналога с одним классом акций. Одним из основных факторов, влияющих на дисконт к стоимости, является размер личных выгод. В отраслях с высокими нематериальными выгодами, такими как отрасль «медиа», «индустрия развлечений», «спортивные клубы», дисконт к стоимости максимален.

Однако выпуск акций с разными правами голоса может быть выгоден для всех акционеров, а именно, когда стратегические и финансовые аспекты играют решающую роль при принятии решения о выпуске акций с разными правами голоса. Он может быть выгоден для компаний типа «старт-ап», компаний из наукоемких отраслей, «медиа», «финансовые услуги». На практике, количество компаний, использующих избыточные права на контроль для реализации стратегических и финансовых преимуществ, не высоко, и носит единичный характер.

Суммируя результаты, отметим, что выпуск акций с разными правами голоса сопряжен с большими агентскими издержками, что в полной мере подтверждается и теорией и практикой. Агентские издержки тем выше, чем выше личные выгоды от контроля, которые складываются как из выгод материального, так и нематериального характера. В среднем издержки, возникающие при выпуске акций с разными правами голоса, все же превышают выгоды. В связи с наличием высоких агентских издержек в компаниях, имеющих в структуре акционерного капитала акции с разными правами голоса, а также в силу слабой защиты прав миноритарных акционеров в России, снятие запрета на выпуск акций с разными правами представляется нецелесообразным. 


\section{Список литературы}

1. Almeida H., Wolfenzon D., "A Theory of Pyramidal Ownership and Family Business Groups". Working paper. Stern School of Business, New York University and the National Bureau of Economic Research.

2. Amoako-Adu, B. and Smith, B. Dual class firms: Capitalization, ownership structure and recapitalization back into single class, Journal of Banking and Finance 25, 2001.

3. Berle A. Jr., Means G.C., The Modern Corporation and Private Property, New York, The Macmillan Company, 1933.

4. Bebchuk L., Kraakman R., Triantis G., "Stock Pyramids, Cross-Ownership, and Dual Class Equity: The Creation and Agency Costs of Separating Control From Cash-Flow Rights". Concentrated Corporate Ownership (R. Morck, ed.), 2000.

5. Bennedsen, M. and K.M. Nielsen, "The Principle of Proportional Ownership, Investor Protection and Firm Value in Western Europe", Working paper, Copenhagen Business School, May 2008.

6. Boubaker S., "Ownership-Control Discrepancy and Firm Value: Evidence from France", Multinational Finance Journal, vol. 11, no. 3/4, 2007.

7. Chemmanur T.J., Jiao Y., "Dual Class IPOs, Share Recapitalizations, and Unifications: A Theoretical Analysis". ECGI Working Paper Series in Finance. Working Paper $\mathrm{N}^{\circ} .129 / 2006$.

8. Claessens, S., S. Djankov, J.P.H. Fan and L.H.P. Lang., "Disentangling the Incentive and Entrenchment Effects of Large Shareholdings", The Journal of Finance 57, 2002.

9. Cronqvist, H. and M. Nilsson., "Agency Costs of Controlling Minority Shareholders", Journal of Financial and Quantitative Analysis 38, 2003.

10. DeAngelo H., and L. DeAngelo., "Managerial Ownership of Voting Rights", Journal of Financial Economics 14, 1985.

11. Demsetz, H. and K. Lehn, "The Structure of Corporate Ownership: Causes and Consequences", Journal of Political Economy 93, 1985.

12. Gompers, P. A., J. Ishii and A. Metrick., "Extreme Governance: An Analysis of U.S. DualClass Companies in the United States", Working Paper, Harvard Business School, 2004.

13. Grossman S.J., Hart O.D., "One share one vote and the market for corporate control". Journal of Financial Economics 20, 1988.

14. Jarrell G. A., and A. B. Poulsen, Dual-Class Recapitalizations as Antitakeover Mechanisms: The Recent Evidence, Journal of Financial Economics, 20, 1988.

15. Harris M., Raviv A., "Corporate governance voting rights and majority rules", Journal of Financial Economics 20, 1988.

16. ISS, Sherman and Sterling and European Corporate Governance Institute, "Report on the Proportionality Principle in the European Union", May 2007. $\mathrm{http} / / / \mathrm{www}$.ecgi.org/osov/documents/final_report_en.pdf

17. La Porta R., Lopez-de-Silanes, F., Shleifer A., "Corporate Ownership around the World. The Journal of Finance", Vol. 54, No. 2, Apr., 1999.

18. Lins K. V., "Equity Ownership and Firm Value in Emerging Markets", Journal of Financial and Quantitative Analysis 38, 2003.

19. Maury, B. and A. Pajuste, "Multiple Controlling Shareholders and Firm Value", Journal of Banking and Finance 29, 2004.

20. Masulis W., Wang C., Xie F., "Agency Problems at Dual-Class Companies". Working paper. Vanderbilt University, 2006.

21. Megginson, W., "Restricted voting stock, acquisition premiums, and the market value of corporate control", The Financial Review 25, 1990.

22. Morck R., A. Shleifer and R. Vishny, "Management Ownership and Corporate Performance: An Empirical Analysis", Journal of Financial Economics 20, 1988. 
23. Nenova T., "How to dominate a firm with valuable control: Regulation, security-voting structure, and ownership patterns of dual-class firms". Unpublished working paper. Harvard University, Cambridge, MA, 2001.

24. Nenova T., "The Value of Corporate Voting Rights and Control: A Cross-Country Analysis", Journal of Financial Economics 68, 2003.

25. Megan P., "The creation of a class of limited voting common stock and shareholders wealth", Journal of Financial Economics 18, 1987.

26. Smart, S. and Zutter, C., "Control as a motivation for underpricing: A comparison of dual and single-class IPOs", Journal of Financial Economics 69, 2003.

27. Villalonga, B. and R. Amit, "How are US Family Firms Controlled?", Working paper, The Wharton School, 2006. 